\title{
Dual crop coefficient for the early-cycle soybean cultivar SoyTech 815 RR
}

\author{
Guilherme Bariviera $^{1}$, Rivanildo Dallacort ${ }^{1}$, Paulo S. L. de Freitas ${ }^{2}$, Joao D. Barbieri ${ }^{2}$ \& Diego F. Daniel ${ }^{1}$ \\ ${ }^{1}$ Universidade do Estado de Mato Grosso/Departamento de Agronomia. Tangará da Serra, MT, Brasil. E-mail: guilherme.bariviera@hotmail.com - \\ ORCID: 0000-0003-3330-6893; rivanildo@unemat.br - ORCID: 0000-0002-7634-8973; diegodanielmt@gmail.com - ORCID: 0000-0003-1743-5089 \\ ${ }^{2}$ Universidade Estadual de Maringá/Pós-Graduação em Agronomia. Maringá, PR, Brasil. E-mail: jd.barbieri@hotmail.com (Corresponding author) - \\ ORCID: 0000-0002-8251-1255; pslfreitas@uem.br - ORCID: 0000-0001-6663-2797
}

\begin{abstract}
The objective of this study was to determine the dual crop coefficient of an early-cycle soybean cultivar for the city of Tangará da Serra, MT, Brazil, using high-precision lysimeters. The method used was the dual crop coefficient (dual Kc) of FAO Bulletin 56, constitued by soil evaporation coefficient (Ke), determined by microlysimeters, and by basal crop coefficient (Kcb), determined by weighing lysimeters. Reference evapotranspiration (ETo) was calculated using the Penman-Monteith equation. Soybean sowing and harvesting were performed in the $2015 / 16$ season with spacing of $0.45 \mathrm{~m}$ between rows. The reference evapotranspiration (ETo) estimated for the cultivation period was $267.06 \mathrm{~mm}$; the crop evapotranspiration was $323.61 \mathrm{~mm}$ throughout its cycle. The Kcb values determined by lysimeters for soybean cultivation were 0.47 , 1.15 and 0.89 for the initial, intermediate and final stages, respectively; Ke values at the initial, intermediate and final stages were $0.94,0.14$ and 0.44 , respectively.
\end{abstract}

Key words: Glycine max (L.) Merril, water balance, lysimeters, microlysimeters

\section{Coeficiente de cultivo dual para a cultivar de soja SoyTech 815 RR de ciclo precoce}

RESUMO: Objetivou-se com esta pesquisa, determinar o coeficiente duplo de cultivo de uma cultivar de soja de ciclo precoce para o município de Tangará da Serra, MT, utilizando lisímetros de pesagem de alta precisão. O método utilizado foi o do coeficiente de cultivo dual (Kc dual) do Boletim 56 da FAO, constituido pelo coeficiente de evaporação do solo (Ke), determinado por microlisímetros e pelo coeficiente basal da cultura (Kcb), determinado por lisímetros de pesagem. Para o cálculo da evapotranspiração de referência (ETo) utilizou a equação de Penman-Monteith. A semeadura e a colheita da soja foram realizadas na safra 2015/16 com espaçamento entre fileiras de 0,45 m. A evapotranspiração de referência (ETo) estimada para o período de cultivo foi de $267,06 \mathrm{~mm}$; a evapotranspiração da cultura foi de 323,61 mm durante todo seu ciclo. O valor de Kcb determinado por lisímetros para o cultivo da soja foi de 0,47, 1,15 e 0,89 para a fase inicial, intermediária e final, respectivamente; para o Ke, nas fases inicial, intermediária e final foi de 0,94, 0,14 e 0,44 , respectivamente.

Palavras-chave: Glycine max (L.) Merril, balanço hídrico, lisímetros, microlisímetros 


\section{INTRODUCTION}

Water is the main limiting factor for soybean to express all its production potential, as it acts on virtually all physiological and biochemical processes of the crop, besides constituting most of the plant's weight (Farias et al., 2007; Silva et al., 2014).

The irrigation system becomes a widely used tool to increase yields, but it is necessary to perform a correct water management and correctly design the system. Paço et al. (2014) comment that accurately determining water consumption by the crop, that is, crop evapotranspiration, is of fundamental importance for allowing irrigation management to be optimized.

Evapotranspiration values are used to determine the dual crop coefficient (dual Kc), and FAO Bulletin 56 defined that Kc can be divided into two components, aiming to improve the efficiency of measuring the water consumption of plants under field conditions. This methodology is based on the determination of the soil evaporation coefficient $(\mathrm{Ke})$, as the ratio between soil evaporation and reference evapotranspiration (ETo), and on the determination of the basal crop coefficient (Kcb), as the ratio between plant transpiration and ETo (Allen et al., 1998).

Research studies aiming to determine agrometeorological indices in order to minimize the effects of water deficit on crops are of great importance, especially with the current development of new soybean cultivars, with increasingly earlier cycles, thus promoting the improvement of agroclimatic zoning, with emphasis on the reduction of risks in grain production.

Thus, by determining the dual crop coefficient it is possible to separately verify how soil water evaporation and crop transpiration occur. In general, studies like this aim to improve water conservation issues and management of irrigation water, pointing to its environmental and economic importance, and so far there are no studies on the soybean crop in the state of Mato Grosso, Brazil.

The objective of the present study was to determine the evapotranspiration and dual crop coefficient for an early-cycle soybean cultivar, using weighing lysimeters for the region of Tangará da Serra, MT, Brazil.

\section{Material ANd Methods}

The study was carried out in the experimental area of the Universidade Estadual do Mato Grosso, UNEMAT, Campus of Tangará da Serra, Brazil, at geographic coordinates $14^{\circ}$ $65^{\prime} 00^{\prime \prime} \mathrm{S}, 57^{\circ} 43^{\prime} 15^{\prime \prime} \mathrm{W}$ and altitude of $440 \mathrm{~m}$. According to Köppen's classification, the climate of the region is classified as megathermal humid tropical (AW), with a dry season, comprising the months from May to September, and a rainy season, which occurs from October to April, showing average annual rainfall of $1,830 \mathrm{~mm}$ and mean air temperature of 26.1 ${ }^{\circ} \mathrm{C}$ (Dallacort et al., 2011), with soil classified as Oxisol with very clayey texture.

Close to the experimental area, there is an automatic weather station, which was used for collecting data of temperature, precipitation, solar radiation, wind speed, air relative humidity and atmospheric pressure, which are used to determine the reference evapotranspiration - ETo, which was calculated using the FAO-56 Penman-Monteith methodology, proposed by Allen et al. (1998), used by Santos et al. (2014) and Vieira et al. (2016), as shown in Eq. 1.

$$
\text { ETo }=\frac{0.408 \Delta(\mathrm{Rn}-\mathrm{G})+\gamma \frac{900}{\mathrm{~T}+273} \mathrm{U}_{2}\left(\mathrm{e}_{\mathrm{s}}-\mathrm{e}_{\mathrm{a}}\right)}{\Delta+\gamma\left(1+0.3 \mathrm{U}_{2}\right)}
$$

where:

ETo - reference evapotranspiration, $\mathrm{mm} \mathrm{d}^{-1}$;

$\mathrm{Rn}$ - net solar radiation on the crop, $\mathrm{MJ} \mathrm{m}^{-2} \mathrm{~d}^{-1}$;

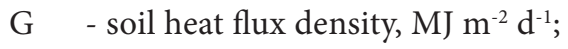

$\mathrm{T} \quad$ - air temperature at $2 \mathrm{~m}$ height, ${ }^{\circ} \mathrm{C}$;

$\mathrm{U}_{2} \quad$ - wind speed at $2 \mathrm{~m}$ height, $\mathrm{m} \mathrm{s}^{-1}$;

$\mathrm{e}_{\mathrm{s}} \quad$ - saturation vapor pressure $(\mathrm{kPa})$, estimated by the average of $\mathrm{e}_{\mathrm{s}}(\operatorname{Tmax})$ and $\mathrm{e}_{\mathrm{s}}(\mathrm{Tmin})$;

$\mathrm{e}_{\mathrm{a}} \quad$ - actual vapor pressure, $\mathrm{kPa}$;

$\Delta \quad$ - slope of the vapor pressure curve, $\mathrm{kPa}^{\circ} \mathrm{C}^{-1}$; and,

$\gamma \quad$ - psychrometric constant, $\mathrm{kPa}^{\circ} \mathrm{C}^{-1}$.

The experiment was conducted using two high-precision weighing lysimeters with area of $2.25 \mathrm{~m}^{2}(1.5 \times 1.5 \mathrm{~m})$ and depth of $1.20 \mathrm{~m}$. These lysimeters were previously calibrated, according to the methodology of Faria et al. (2006) and used by Fenner et al. (2019), aiming to establish the relationship between the signal emitted by the load cell in millivolt $(\mathrm{mV})$ and the fluctuation in the mass of the set $(\mathrm{kg})$, which occurs through evapotranspiration, irrigation, precipitation and drainage.

In addition, four microlysimeters were also used, composed of 150-mm-diameter and 300-mm-height PVC pipe, installed beside the weighing lysimeters, in which soil water evaporation was quantified based on the methodology proposed by Flumignan et al. (2012). Weighing was performed every day in the morning on a precision scale, which allowed observing the mass variation from one day to the next.

Soybean was sown on November 18, 2015, and harvested on March 09, 2016, using the early-cycle cultivar SoyTech 815 RR, with spacing of $0.45 \mathrm{~m}$ between rows. Soil and crop fertilization corrections were based on soil chemical analysis according to their respective nutritional requirements, whereas the cultural practices, such as management of pest, diseases and weeds, were carried out when needed using herbicides, insecticides and fungicides recommended for the crop.

The irrigations were performed using a fixed conventional sprinkler system, consisting of four sprinklers (Eco 232 Fabrimar) with spacing of $12 \times 12 \mathrm{~m}$, covering the entire experimental area, with Christiansen's uniformity coefficient (CUC) of $86 \%$, under pressure of 30 m.w.c., meeting the water needs of the crop along its development without water deficit.

The microlysimeters were used to determine water evaporation from the soil $\left(\mathrm{E}_{\mathrm{ML}}\right)$, according to the methodology proposed and adapted by Flumignan et al. (2012), according to Eq. 2.

$$
\mathrm{E}_{\mathrm{ML}}=\frac{\Delta \mathrm{M}_{\mathrm{ML}}}{\mathrm{A}_{\mathrm{ML}}}+\mathrm{P}
$$


where:

$\mathrm{E}_{\mathrm{ML}}$ - evaporation of microlysimeter, $\mathrm{mm}$;

$\Delta \mathrm{M}_{\mathrm{ML}}$ - mass variation of the microlysimeters, $\mathrm{kg}$;

$\mathrm{A}_{\mathrm{ML}}$ - area of the microlysimeters, $\mathrm{m}^{2}$; and,

$\mathrm{P}$ - precipitation, $\mathrm{mm}$.

The soil evaporation coefficient $\left(\mathrm{K}_{\mathrm{e}}\right)$ was determined daily by the relationship between soil evaporation $\left(\mathrm{mm} \mathrm{d}^{-1}\right)$ and reference evapotranspiration $\left(\mathrm{mm} \mathrm{d}^{-1}\right)$, according to the methodology proposed by Flumignan et al. (2012), expressed by Eq. 3 .

$$
\mathrm{Ke}=\frac{\mathrm{E}_{\mathrm{ML}}}{\mathrm{ETo}}
$$

where:

Ke - soil evaporation coefficient;

$\mathrm{E}_{\mathrm{ML}}$ - evaporation of microlysimeters, $\mathrm{mm}$; and,

ETo - reference evapotranspiration (FAO-56 PenmanMonteith method, mm).

Crop evapotranspiration (ETc) was obtained daily, based on the mass variation of the weighing lysimeters, between 06:00 and 18:00 h, and subsequently converted to millimeters $\left(\mathrm{mm} \mathrm{d}^{-1}\right)$, through the calibration equation of the lysimeters, according to the methodology of Faria et al. (2006), Mendonça et al. (2007) and Fenner et al. (2019). ETc was determined according to Eq. 4:

$$
\mathrm{ETc}=\frac{\mathrm{M}_{\mathrm{i}(06: 00)}-\mathrm{M}_{\mathrm{i}-1(18: 00)}}{\mathrm{A} \Delta \mathrm{T}}
$$

where:

ETc - crop evapotranspiration, $\mathrm{mm} \mathrm{d}^{-1}$;

$M_{i} \quad$ - initial mass of the lysimeter at 06:00 h;

$\mathrm{M}_{\mathrm{i}-1}$ - final mass of the lysimeter at 18:00 h;

A - lysimeter area, $\mathrm{m}^{2}$; and,

$\Delta \mathrm{T}$ - time period.

Basal crop coefficient was determined according to the methodology of FAO Bulletin 56 (Allen et al., 1998), used by Silva et al. (2013) and Fenner et al. (2016), as shown in Eq. 5.

$$
\mathrm{K}_{\mathrm{cb}}=\left(\frac{\mathrm{ETc}}{\mathrm{ET}_{\mathrm{o}}}\right)-\mathrm{Ke}
$$

where:

Kcb - basal crop coefficient;

ETc - crop coefficient, $\mathrm{mm} \mathrm{d}^{-1}$;

ETo - reference evapotranspiration, $\mathrm{mm} \mathrm{d}^{-1}$; and,

$\mathrm{Ke}$ - soil evaporation coefficient, $\mathrm{mm} \mathrm{d}^{-1}$.

For the estimated values of $\mathrm{Kcb}$ and Ke, the standardized methodology of the FAO Bulletin 56 was used (Allen et al., 1998), according to Eqs. 6 and 7:

$\mathrm{Kcb}=\mathrm{Kcb}_{(\mathrm{tab})}+\left[0.04\left(\mathrm{U}_{2}-2\right)-0.004\left(\mathrm{RH}_{\min }-45\right)\right] \times\left(\frac{\mathrm{h}}{3}\right)^{0.3}$ where:

$\mathrm{Kcb}_{\text {(tab) }}$ - value of $\mathrm{Kcb}_{\text {mid }}$ or $\mathrm{Kcb}_{\text {end }}$, originated from Table 17 of FAO Bulletin 56;

$\mathrm{U}_{2} \quad$ - average wind speed at $2 \mathrm{~m}$ height above standard vegetation, $\mathrm{m} \mathrm{s}^{-1}$;

$\mathrm{RH}_{\text {min }}$ - average value of minimum air relative humidity, \%;

$\mathrm{h}$ - average crop height during intermediate and final stages (m) (Table 12 of FAO Bulletin 56).

$$
\mathrm{Ke}=\mathrm{Kr}\left(\mathrm{Kc}_{\max }-\mathrm{Kcb}\right) \leq \text { few } \mathrm{Kc}_{\max }
$$

where:

$\mathrm{Kc}_{\max }$ - maximum value of $\mathrm{Kc}$ after rainfall or irrigation;

$\mathrm{Kr}$ - evaporation reduction coefficient dependent on the cumulative amount of water depleted (evaporated) from soil surface; and,

few - fraction of superficial evaporation from the soil.

The phenological stages of the crop were determined in order to determine the coefficients in the different development stages, and the initial, intermediate and final Kcb and Ke were established as described by Mendonça et al. (2007). The values of ETo and ETc were used to determine the daily values of single $\mathrm{Kc}$ in the stages of soybean crop, which is the relationship between crop evapotranspiration (ETc) and reference evapotranspiration (ETo), i.e. $(\mathrm{Kc}=\mathrm{ETc} / \mathrm{ETo})$.

\section{Results AND Discussion}

Figure 1 presents the data of precipitation, irrigation depth and average, minimum and maximum temperatures during the 113 days of crop cycle. During soybean cultivation, there were 62 precipitation events and five irrigation events, totaling 922.28 and $77 \mathrm{~mm}$, respectively. The average temperature was $25.75^{\circ} \mathrm{C}$ along the experimental period. These values are close to the average rainfall and temperature values for the study region, as described by Dallacort et al. (2011).

By analyzing the water balance extract for ten-day periods along the experiment, it was observed that there was no water deficit for the soybean crop, so the Kc of the crop was determined in period without water restriction (Figure 2).

According to EMBRAPA (2011), the ideal temperature for soybean development is around 20 to $30^{\circ} \mathrm{C}$, with $25^{\circ} \mathrm{C}$ being the ideal temperature, and the water requirement of the crop varies from 450 to $800 \mathrm{~mm}$. The values found in this study are within the range recommended for the crop.

There is a direct influence of precipitation on the behavior of air temperature, because in the days in which precipitation occurred, it caused a reduction in the ambient temperature. Fenner et al. (2016) report this same behavior in a study conducted in the same region, and infer that the reduction in ambient temperature causes a reduction in the amount of energy supplied for the crop and reference evapotranspiration.

The reference evapotranspiration (ETo) varied between maximum and minimum values of 4.56 and $0.61 \mathrm{~mm} \mathrm{~d}^{-1}$ respectively, totaling a volume of $267.06 \mathrm{~mm}$ for the crop cycle.

The accumulated value of ETc was $295.32 \mathrm{~mm}$ for the entire period of crop development, with maximum evapotranspiration of $5.25 \mathrm{~mm} \mathrm{~d}^{-1}$ and minimum of $0.68 \mathrm{~mm} \mathrm{~d}^{-1}$ (Figure 3). 


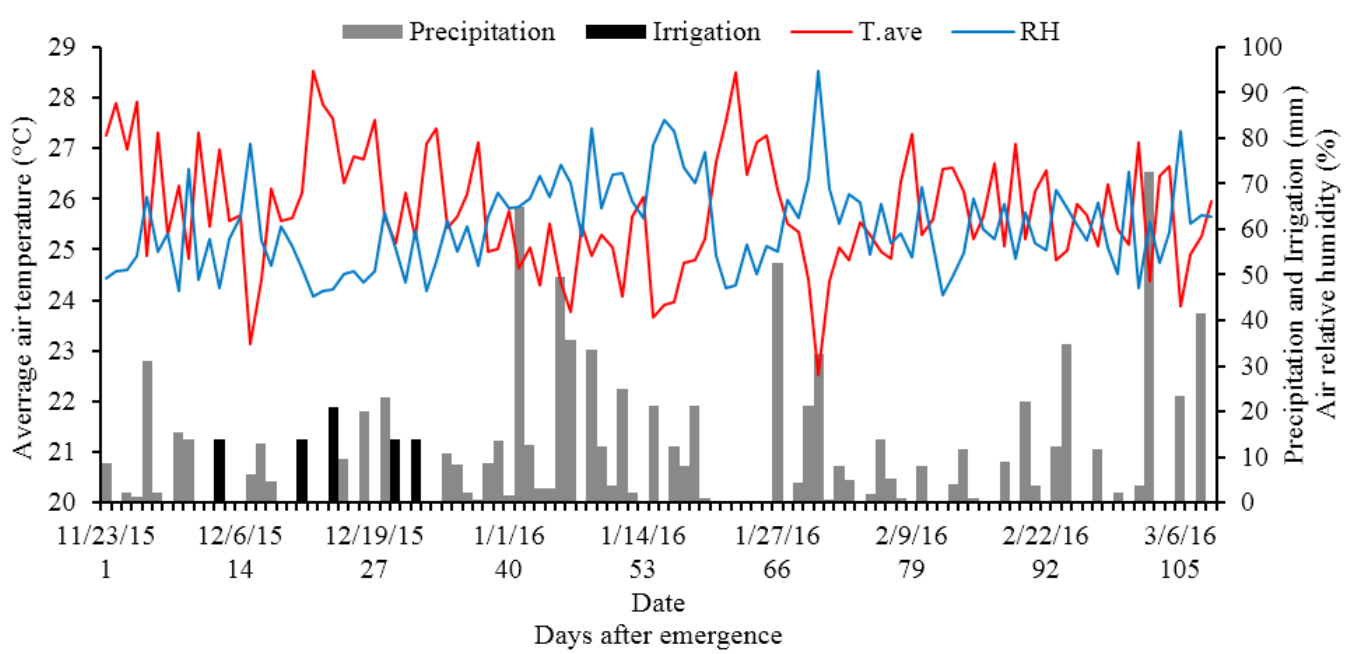

Figure 1. Irrigation depth, precipitation, average temperature (T.ave) and air relative humidity (RH) along the soybean crop development in Tangará da Serra, MT

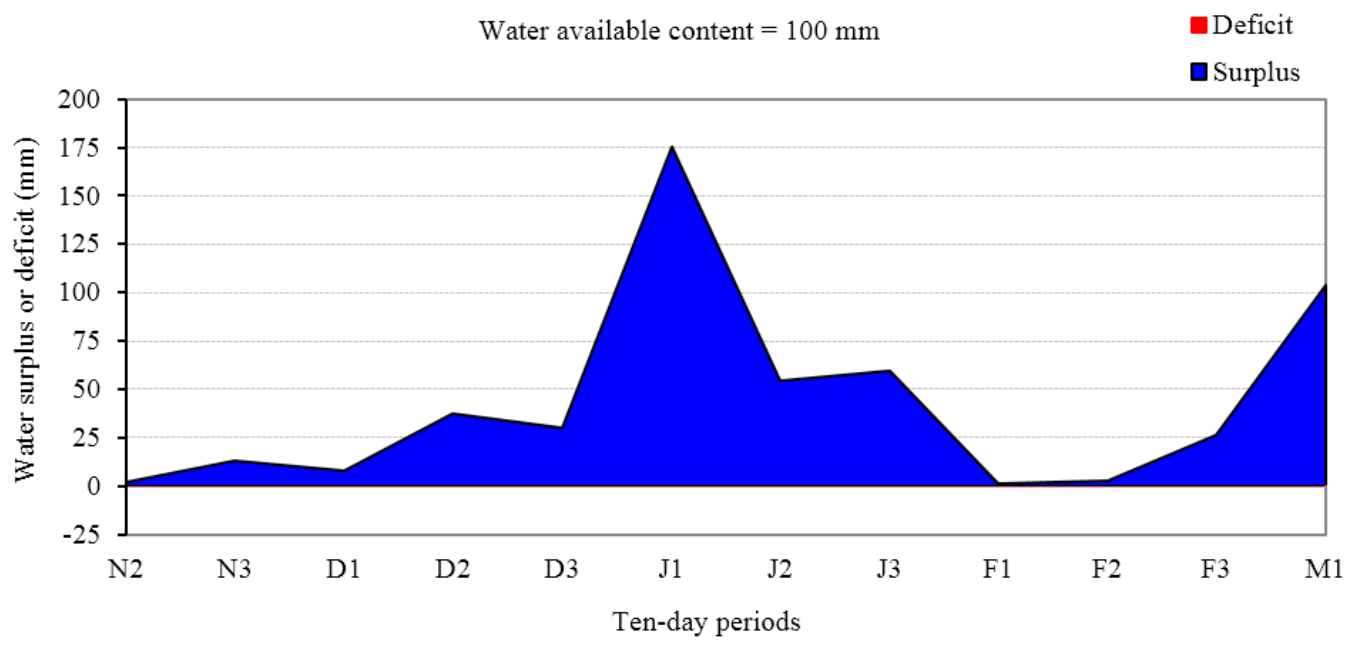

The letters in the $\mathrm{x}$ axis represent the mounths

Figure 2. Ten-day period water balance along the experiment between November 18, 2015 and March 03, 2019, in Tangará da Serra, MT

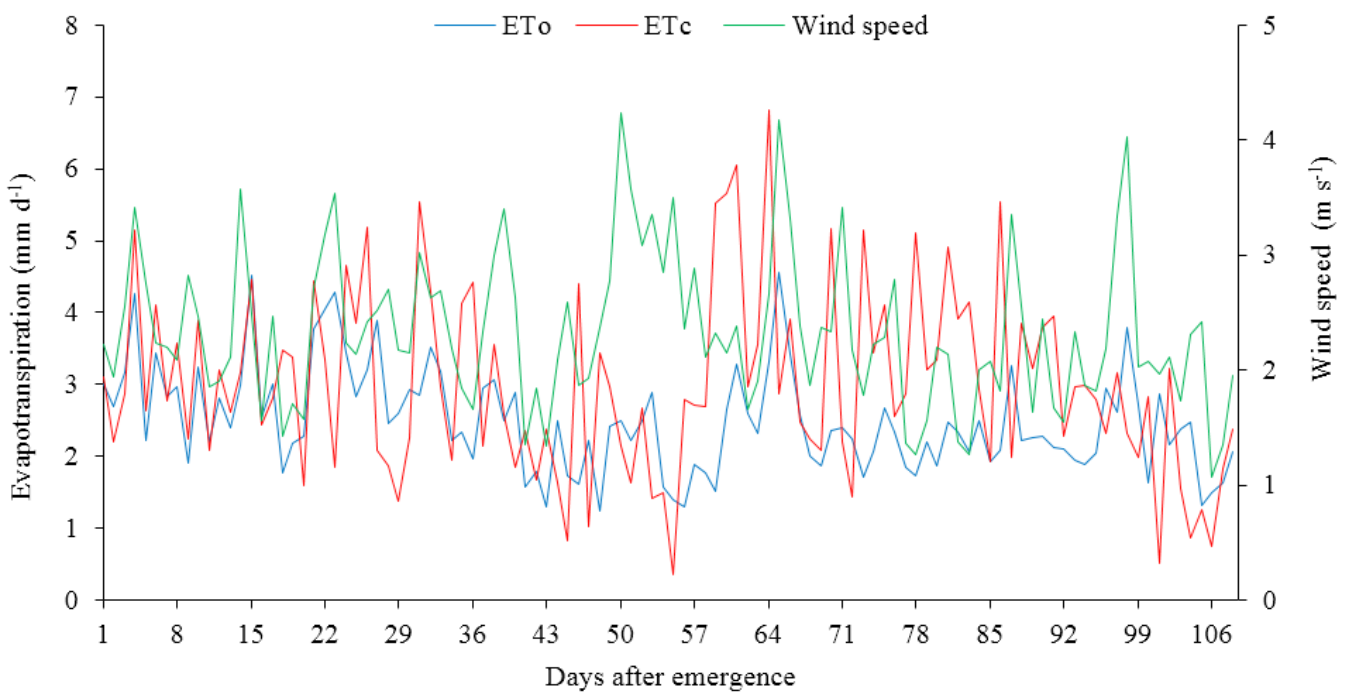

Figure 3. Daily values of ETo, ETc and wind speed for the soybean cultivation period in the region of Tangará da Serra, MT

The ETc measured in the weighing lysimeters had accumulated value of $323.61 \mathrm{~mm}$ during the cycle, with minimum evapotranspiration of $0.35 \mathrm{~mm} \mathrm{~d}^{-1}$ and maximum of $6.82 \mathrm{~mm} \mathrm{~d}^{-1}$, at 56 days after emergence (DAE) and at $64 \mathrm{DAE}$, respectively. This variation occurs due to climatic variations, and the main element is the air relative humidity, which for these days showed minimum values of 81.4 and $50.3 \%$, respectively, for the minimum and maximum values of ETc. However, it is 
possible to affirm that in days with low air relative humidity, the evapotranspiration is high, since the soil was kept at a moisture content close to field capacity, favoring large water transfer in the soil-plant-atmosphere system. For the studied period, the average wind speed recorded at the station was $2.33 \mathrm{~m} \mathrm{~s}^{-1}$, with maximum of $4.23 \mathrm{~m} \mathrm{~s}^{-1}$ and minimum of $1.07 \mathrm{~m} \mathrm{~s}^{-1}$.

The observed value of maximum crop evapotranspiration coincided with the grain filling stage (R5) of the crop, characterized as the most sensitive to water deficit and the one with highest water requirement by the crop (Farias et al., 2007).

According to Doorenbos \& Kassam (1994), in order to obtain high soybean yields, it is necessary to supply a water depth between 450 and $850 \mathrm{~mm}$, distributed throughout the cycle. Vivan et al. (2013) studied nine scenarios of soybean cultivation in the region of the Rio Grande do Sul Plateau, under humid subtropical climate (Cfa), with rainfall well distributed along the year and average temperature of $17.5^{\circ} \mathrm{C}$, and observed the need for application of supplementary irrigation depth in all scenarios, ranging from 163.48 to $238.60 \mathrm{~mm}$.

Suyker \& Verma (2009) studied soybean evapotranspiration at the University of Nebraska, USA, for rainfed and irrigated systems, under climate classified as Dfa according to Köppen and average temperature of $10.6^{\circ} \mathrm{C}$, and found ETc values from 420 to $441 \mathrm{~mm}$ and from 430 to $470 \mathrm{~mm}$, respectively, which are higher than those obtained in this study.

By dividing the crop evapotranspiration into evaporation and transpiration, it can be observed that this relationship showed values of $38.33 \%$ for evaporation and $61.67 \%$ for transpiration, i.e., although the evaporative demand from the soil was high at the beginning of the crop development, most of the water present in the medium is consumed by the plant. In the initial stage of the crop, evaporation has higher values, because in this period the leaf area index is low, so the soil received more solar energy and thus there was greater loss of water to the atmosphere (Oliveira et al., 2014).

Figure 4 shows the behavior of Ke and Kcb for soybean cultivated in Tangará da Serra, MT, for the period of crop development. For Ke, the greatest potential of evaporation concentrates in the initial stage of crop development, as it has the ideal characteristics for this event, such as little cover of soil surface, direct incidence of solar rays on the soil, combined with soil moisture, whereas the lowest values are found in the other stages of crop development.

In the initial stage of the crop, when its leaf area index is low, there is a high evaporation rate, because the irrigation system maintains the soil close to field capacity, facilitating water evaporation in the surface layer of the soil.

During the experimental period, the soil was kept always close to field capacity, a condition of fundamental importance to determine the values of Ke. Gava et al. (2013) report that evaporation is dependent on soil moisture, i.e., the amount of water that can be evaporated. According to Allen et al. (1998), after being wet, the soil shows maximum evaporation rate; however, when it starts to dry, the evaporation decreases, since there is less water available for this event.

The Kcb had inverse behavior to that of Ke. At the beginning, there were low values of $\mathrm{Kcb}$, because evaporation occurs more intensely, whereas at the intermediate stage, it reaches the maximum value, because the plant is at full development, decreasing in the final stage of the crop. Allen et al. (1998) reported this same behavior for both the single Kc and the dual Kc. In a study conducted by Fenner et al. (2016), the same behavior was observed in common beans.

Table 1 presents the values of soil water evaporation coefficient $(\mathrm{Ke})$ measured by microlysimeters and those estimated by the method of FAO Bulletin 56 (Allen et al., 1998), for the period of soybean cultivation.

The behavior of soil evaporation changes as the crop grows, with the highest values of evaporation at the beginning of crop development, due to the low leaf area index, which favors soil

Table 1. Average soil evaporation coefficient (Ke), measured in microlysimeters and estimated by method of FAO Bulletin 56 for the region of Tangará da Serra, MT

\begin{tabular}{cccc}
\hline \multirow{2}{*}{$\begin{array}{c}\text { Evaporation } \\
\text { coefficient (Ke) }\end{array}$} & \multicolumn{3}{c|}{ Development stages (duration - days) } \\
\cline { 2 - 4 } & Initial & Intermediate & Final \\
\cline { 2 - 4 } Measured & $\mathbf{3 5}$ & $\mathbf{5 0}$ & $\mathbf{2 3}$ \\
Estimated & 0.94 & 0.14 & 0.44 \\
Difference & 0.60 & 0.02 & 0.25 \\
\hline
\end{tabular}

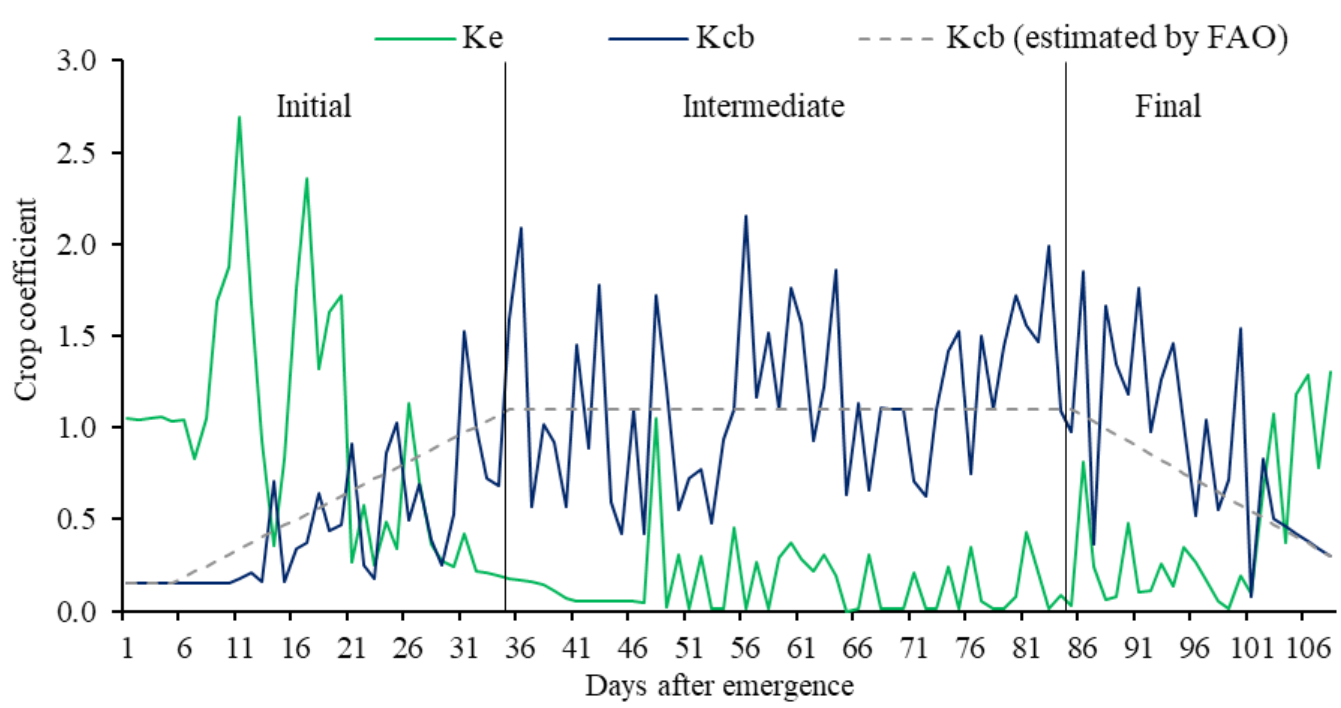

Figure 4. Evaporation coefficient (Ke), basal crop coefficient (Kcb) and basal crop coefficient estimated by FAO (estimated Kcb) during the soybean cycle in the region of Tangará da Serra, MT 
water evaporation. Subsequently, at the intermediate stage, there is a reduction in evaporation rate, as the entire leaf area of the plant is developed, fully covering the soil surface. At the final stage, when leaves fallen due to senescence cover part of the soil, there is an elevation in the values of evaporation, but these are lower than the values found in the initial stage.

Table 2 shows the values of basal crop coefficient $(\mathrm{Kcb})$ measured and estimated for soybean along its development period in Tangará da Serra, MT.

The mean values of Kcb measured for the initial, intermediate and final stages of soybean crop were $0.47,1.15$ and 0.89 , respectively. This behavior is related to the development of the crop, in which at the beginning plants are developing and their root system is forming, which leads to low water consumption. In the intermediate stage, plants have maximum leaf area index, and the absorption of water and nutrients by their roots is large, promoting high water consumption.

Bastos et al. (2007) found different Kc values for soybean from those observed in the present study, for the region Alvorada da Gurguéia, using the soybean cultivar Tracajá. These authors observed values of $0.38,1.04$ and 0.8 for the initial, intermediate and final stages, respectively.

The differences between the measured and estimated Kcb values are presented in Table 2, which shows that there were lower values of measured $\mathrm{Kcb}$ at the beginning of the crop development $(-0.10)$ and higher values in the intermediate and final stages, 0.05 and 0.21 respectively. These differences may be related to the cultivar selected for the study. For the intermediate and final stages, Allen et al. (1998) report that, when the soil is fully covered by the crop, the Kc mainly reflects its transpiration, because the contribution of evaporation is low.

The mean values of single crop coefficient (single Kc) represented by the relationship between crop evapotranspiration (ETc) and reference evapotranspiration (ETo) in this study corresponded to $1.10,1.44$ and 1.17 for the initial, intermediate and final stages of the crop, respectively, different from the values estimated by FAO, which are $0.50,1.15$ and 0.50 in the initial, intermediate and final stages, respectively. The single Kc values measured in the lysimeters were higher than the Kc values modeled according to FAO in Allen et al. (1998). This demonstrates that the utilization of measured values is more recommended, because using FAO-tabulated values may lead to underestimation of the water needs of soybean cultivated in the region of Tangará da Serra, MT, in all stages.

Table 2. Basal crop coefficient of soybean $(\mathrm{Kcb})$ for the region of Tangará da Serra, MT, measured by weighing lysimeters and estimated by the FAO Bulletin 56

\begin{tabular}{cccc}
\hline \multirow{2}{*}{$\begin{array}{c}\text { Basal crop } \\
\text { coefficient (Kcb) }\end{array}$} & \multicolumn{3}{c}{ Development stages (duration - days) } \\
\cline { 2 - 4 } & Initial & Intermediate & Final \\
\cline { 2 - 4 } Measured & $\mathbf{3 5}$ & $\mathbf{5 0}$ & $\mathbf{2 3}$ \\
Estimated & 0.47 & 1.15 & 0.89 \\
Difference & 0.57 & 1.10 & 0.68 \\
\hline
\end{tabular}

\section{Conclusions}

1. During the initial stage of the soybean cultivar SoyTech 815 RR, soil evaporation rate was, above the values estimated by FAO Bulletin 56 .
2. As the crop development progressed, the participation of soil evaporation decreased progressively until it became the smallest part of the evapotranspiration process, due to the increase in the fraction of soil cover by the vegetative canopy of the crop.

3. The intermediate stage of crop development showed the highest transpiration and lowest rates of soil evaporation, indicating the importance of adequate water management to achieve high levels of yield.

4. The observed values of soil evaporation coefficient $(\mathrm{Ke})$ and basal crop coefficient (Kcb) were equal to $0.94,0.14$ and 0.44 and to $0.47,1.15$ and 0.89 for the initial, intermediate and final stages, respectively.

\section{ACKNOWLEDgMents}

To Fundação de Amparo à Pesquisa do Estado de Mato Grosso - FAPEMAT for granting the scientific initiation scholarship, to the Centro de Geoprocessamento e Sensoriamento Remoto - CETEGEO-SR, and to the Universidade Estadual do Mato Grosso - UNEMAT.

\section{Literature Cited}

Allen, R. G.; Pereira, L.; Raes, D.; Smith, M. Crop evapotranspiration: Guidelines for computing crop water requirements. Rome: FAO, 1998. 326p. Irrigation and Drainage Paper, 56

-Bastos, E. A.; Andrade Júnior, A. S.; Silva, C. R.; Aguila, R. M. D.; Campeche, L. F. de S. M.; Souza, C. F. Coeficiente de cultivo da soja no vale do Gurguéia, PI. In: Congresso Brasileiro de Agrometeorologia, 15, 2007, Aracaju. Anais... Aracaju: CBAGRO, 2007. CD-Rom

Dallacort, R.; Martins, J. A.; Inoue, M. H.; Freitas, P. S. L. de; Coletti, A. J. Distribuição das chuvas no município de Tangará da Serra, médio norte do Estado de Mato Grosso, Brasil. Acta Scientiarum. Agronomy, v.33, p.193-200, 2011. http://dx.doi.org/10.4025/ actasciagron.v33i 2.5838

Doorenbos, J.; Kassam, A. H. Efeito da água no rendimento das culturas. Campina Grande: UFPB, 1994. 306p. Irrigation and Drainage Paper, 33

EMBRAPA - Empresa Brasileira de Pesquisa Agropecuária. Tecnologia de produção da soja: Região central do Brasil 2012 e 2013. Londrina: Embrapa Soja, 2011. 261p.

Faria, R. T. de; Campeche, L. F. de S. M.; Chibana, E. Y. Construção e calibração de lisímetros de alta precisão. Revista Brasileira de Engenharia Agrícola e Ambiental, v.10, p.237-242, 2006. http:// dx.doi.org/10.1590/S1415-43662006000100035

Farias, J. R. B.; Neponuceno, A. L.; Neumaier, N. Ecofisiologia da soja. Londrina: Embrapa Soja, 2007. 9p. Circular Técnica 48

Fenner, W.; Dallacort, R.; Faria Junior, C. A.; Freitas, P. S. L. de, Queiroz, T. M. de; Santi, A. Development, calibration and validation of weighing lysimeters for measurement of evapotranspiration of crops. Revista Brasileira de Engenharia Agrícola e Ambiental, v.23, p.297-302, 2019. https://dx.doi.org/10.1590/1807-1929/ agriambi.v23n4p297-302

Fenner, W.; Dallacort, R.; Freitas, P. S. L. de; Faria Júnior, C. A.; Carvalho, M. A. C. de; Bariviera, G. Dual crop coefficient of common bean in Tangará da Serra, Mato Grosso. Revista Brasileira de Engenharia Agrícola e Ambiental, v.20, p.455-460, 2016. http:// dx.doi.org/10.1590/1807-1929/agriambi.v20n5p455-460 
Flumignan, D. L.; Faria, R. T. de; Lena, B. P. Test of a microlysimeter for of soil evaporation. Engenharia Agrícola, v.32, p.80-90, 2012. http://dx.doi.org/10.1590/S0100-69162012000100009

Gava, R.; Freitas, P. S. L. de; Faria, R. T. de; Rezende, R.; Frizzone, J. A. Soil water evaporation under densities of coverage with vegetable residue. Engenharia Agrícola, v.33, p.89-98, 2013. http://dx.doi. org/10.1590/S0100-69162013000100010

Mendonça, J. C.; Sousa, E. F. de; Bernardo, S.; Sugawara, M. T.; Peçanha, A. L.; Gottardo, R. D. Determinação do coeficiente cultural (Kc) do feijoeiro (Phaseolus vulgaris L.), em Campos dos Goytacazes, RJ. Revista Brasileira de Engenharia Agrícola e Ambiental, v.11, p.471-475, 2007. http://dx.doi.org/10.1590/ S1415-43662007000500004

Oliveira, E. C.; Carvalho, J. de A.; Almeida, E. F. A.; Rezende, F. C.; Santos, B. G.; Mimura, S. N. Evapotranspiration of rose cultivated in protected environment. Revista Brasileira de Engenharia Agrícola e Ambiental, v.18, p.314-321, 2014. http:// dx.doi.org/10.1590/S1415-43662014000300011

Paço, T. A.; Pôças, I.; Cunha, M.; Silvestre, J. C.; Santos, F. L.; Paredes, P.; Pereira, L. S. Evapotranspiration and crop coefficients for a super intensive olive orchard. Na application of SIMDualKc and METRIC models using ground and satellite observations. Journal of Hydrology, v.519, p.2067-2080, 2014. https://doi.org/10.1016/j. jhydrol.2014.09.075
Santos, W. de O.; Espínola Sobrinho, J.; Medeiros, J. F. de; Moura, M. S. B. de; Nunes, R. L. C. Coeficiente de cultivo e necessidades hídrica da cultura do milho verde nas condições do semiárido brasileiro. Irriga, v.19, p.559-572, 2014. http://dx.doi.org/10.15809/irriga.2014v19n4p559

Silva, R. R.; Sartori, M. da G. B.; Wollmann, C. A. Relação entre precipitação pluviométrica e produtividade da cultura de soja, no município de Ibirubá-RS. Revista do Departamento de Geografia USP, v.27, p.296-314, 2014. https://doi.org/10.11606/rdg.v27i0.510 Silva, V. de P. R. da; Tavares, A. L.; Sousa, I. F. de. Evapotranspiração e coeficientes de cultivo simples e dual do coentro. Horticultura Brasileira, v.31, p.255-259, 2013. http://dx.doi.org/10.1590/S010205362013000200013

Suyker, A. E.; Verma, S. B. Evapotranspiration of irrigated and rainfed maize-soybean cropping systems. Agricultural and Forest Meteorology, v.149, p.443-452, 2009. https://doi. org/10.1016/j.agrformet.2008.09.010

Vieira, P. V. D.; Freitas, P. S. L. de; Silva; A. L. B. R. da; Hashiguti, H. T.; Rezende, R.; Faria Junior, C. A. Determination of wheat crop coefficient $(\mathrm{Kc})$ and soil water evaporation $(\mathrm{Ke})$ in Maringa, $\mathrm{PR}$, Brazil. African Journal of Agricultural Research, v.11, p.45514558, 2016. https://doi.org/10.5897/AJAR2016.11377

Vivan, G. A.; Peiter, M. X.; Robaina, A. D.; Barboza, F. da S.; Buske, T. C. Rendimento relativo da cultura da soja em função da lâmina de irrigação. Irriga, v.18, p.282-292, 2013. http://dx.doi.org/10.15809/ irriga.2013v18n2p282 